\title{
СУЧАСНІ СПОСОБИ ОПЕРАТИВНОГО ПОШУКУ ПЕРВИННОЇ ОПЕРАТИВНО-РОЗШУКОВОЇ ІНФОРМАЦІЇ ПІДРОЗДІЛАМИ КРИМІНАЛЬНОЇ ПОЛІЦІї
}

Волошина М. О., Шендрик В. В.

\begin{abstract}
Статтю присвячено визначенню доцільності моніторингу та аналізу мережі Інтернет, соціальних мереж та електронних месенджерів як сучасного способу оперативного пошуку первинної оперативно-розшукової інформації підрозділами кримінальної поліціі. Актуальність теми підтверджується тим, що останніми роками часто з'являються в засобах масової інформації відомості щодо того, що працівники оперативних підрозділів запізно виявляли інформацію про ті чи інші подіі, осіб, обставини вчинення злочину тощо. Аналіз практики діяльності під розділів кримінальної поліції дозволяє стверджувати, що окреслене пов'язано насамперед із тим, що працівниками поліції використовуються зазвичай застарілі способи отримання інформації («робота за напрацьованими схемами та методами»), не використовуються новітні досягнення техніки та наукового прогресу, залишається поза увагою mе, що сьогодні більшу частину свого вільного часу населення проводить в електронному світі. 3'ясовано, що до джерел отримання первинної оперативно-розшукової інформації доцільно віднести: заяви та повідомлення громадян України, іноземних громадян або осіб без громадянства; повідомлення осіб, які конфіденційно співпрацюють з органами внутрішніх справ; повідомлення штатних негласних працівників органів внутрішніх справ; публікаціі (матеріали) засобів масової інформації; матеріали органів дізнання, досудового слідства та суду; запити та інформацію спеціальних служб і правоохоронних органів іноземних держав, міжнародних установ та організацій; орієнтування органів і підрозділів МВС України; офіційні листи та інші матеріали правоохоронних органів України; матеріали контрольно-спостережних справ; запити, офіційні листи та інші матеріали контрольних органів, органів державноі влади та управлінь України, органів місцевого самоврядування, підприємств, установ та організацій; матеріали із комп'ютерної мережі Інтернет.
\end{abstract}

Констатовано, що сьогодні використання оперативного пошуку в мережі Інтернет, соціальних мережах та електронних месенджерах може надати можливість оперативним працівникам отримувати додатково до 20\% первинної оперативно-розшукової інформації, що становить оперативний інтерес.

Ключові слова: оперативний пошук, Інтернет, соціальні мережі, електронні месенджери.

Статья посвящена определению целесообразности мониторинга и анализа сети Интернет, социальных сетей и электронных мессенджеров как современного способа оперативного поиска первичной оперативно-розыскной информации подразделениями криминальной полиции. Актуальность темы подтверждается тем, что в последние годы часто появляются в средствах массовой информации сведения о том, что работники оперативных подразделений поздно получили информацию о тех или иных событиях, человеке, обстоятельствах совершения преступления

Волошина М. О., Шендрик В. В., 2019 и тому подобное. Анализ практики деятельности подразделений криминальной полиции позволяет утверждать, что это связано в первую очередь с тем, что работниками полиции используются обычно устаревшие способы получения информации («работа по наработанным схемам и методам»), не используются новейшие достижения техники и научного прогресса, остается без внимания то, что сегодня большую часть своего свободного времени население проводит в электронном мире. Выяснено, что к источникам получения первичной оперативно-розыскной информации целесообразно отнести: заявления и сообщения граждан Украины, иностранных граждан или лиц без гражданства; уведомления лиц, конфиденциально сотрудничающих с органами внутренних дел; сообщения штатных негласных сотрудников органов внутренних дел; публикации (материалы) средств массовой информации; материалы органов дознания, досудебного следствия и суда; запросы и информацию специальных служб и правоохранительных органов иностранных государств, международных учреждений и организаций; ориентировки органов и подразделений МВД Украины; официальные письма и другие материалы правоохранительных органов Украины; материалы контрольно-наблюдательных дел; запросы, официальные письма и другие материалы контрольных органов, органов государственной власти и управлений Украины, органов местного самоуправления, предприятий, учреждений иорганизаций; материалы из компьютерной сети Интернет.

Констатировано, что сегодня использование оперативного поиска в сети Интернет, социальных сетях и электронных мессенджерах может позволить оперативным работникам получать дополнительно до $20 \%$ первичной оперативно-розыскной информации, составляющей оперативный интерес.

Ключевые слова: оперативный поиск, Интернет, социальные сети, электронные мессенджеры.

The article is devoted to determining the appropriateness of monitoring and analysis of the Internet, social networks and electronic messengers as a modern way to quickly search for primary operational-search information by criminal police units. The relevance of the topic is confirmed by the fact that it is revealed that they are made only by those who use in the modern media information that the operations personnel are being subdivided to check that other employees have worked and, by asserting, have identified the perpetrators. The analysis of criminal police professional work reveals that it is separately open in the first place, in the meantime, what police officers have used in recent cases ("work to create certain schemes and methods") without using new specialists and using scientific programs, using to the fact that most of this free time is spent in the electronic world today. Reported that the source was filled with primary search and search information, which is consistent with the following results: reported and reported citizens of Ukraine, foreign citizens or stateless persons; messages that are confidential to the Internal Affairs; reports of any unspoken work of the police department; publications (materials) of the media; 
adhering materials, pre-trial investigation and courts; record and information of help services and law enforcement agencies of foreign states, international institutions and organizations; keeping the decision and units of the Ministry of Internal Affairs of Ukraine; official letters and other materials of law enforcement agencies of Ukraine; materials of control and warning Warning; records, official lists and other materials of the controlling bodies, entrusted to the authorities and management of Ukraine, local governments, enterprises, institutions and organizations; materials from a computer network Internet. It has been ascertained that today the use of operational search on the Internet, social networks and electronic messengers can allow operational employees to receive an additional $20 \%$ of primary operational search information and be of operational interest.

Key words: operational search, Internet, social networks, electronic messenger.

Постановка проблеми та їі актуальність. Останніми роками часто з'являються в засобах масової інформації відомості щодо того, що працівники оперативних підрозділів запізно виявили інформацію про ті чи інші події, осіб, обставини вчинення злочину тощо. Аналіз практики діяльності підрозділів кримінальної поліції дозволяє стверджувати, що окреслене пов' язано насамперед із тим, що працівниками поліції використовуються зазвичай застарілі способи отримання інформації («робота за напрацьованими схемами та методами»), не використовуються новітні досягнення техніки та наукового прогресу, залишається поза увагою те, що сьогодні більшу частину свого вільного часу населення проводить в електронному світі. Враховуючи вказане, вважаємо доцільним розглянути моніторинг та аналіз мережі Інтернет, соціальних мережі та електронних меседжерів як сучасні способи оперативного пошуку первинної оперативно-розшукової інформації підрозділами кримінальної поліції.

Аналіз останніх досліджень і публікацій. Окремі аспекти здійснення оперативного пошуку первинної оперативно-розшукової інформації розглядалися у працях Л.І. Аркуші, А.В. Баб'яка, Д.В. Бойчука, Е.О. Дідоренка, В.П. Захарова, М.І. Камлика, І.П. Козаченка, О.І. Козаченка, Я.Ю. Кондратьєва, Д.Й. Никифорчука, Ю.Ю. Орлова, В.Л. Ортинського, М.М. Перепелиці, М.А. Погорецького, В.Д. Пчолкіна, М.В. Стащака, А.О. Шелехова, В.В. Шендрика та ін. Однак вченими не досліджувалось питання моніторингу та аналізу мережі Інтернет, соціальних мережі та електронних меседжерів як сучасного способу оперативного пошуку первинної оперативно-розшукової інформації підрозділами кримінальної поліції.

Метою статті $€$ обґрунтування моніторингу та аналізу мережі Інтернет, соціальних мереж та електронних меседжерів як сучасні способи оперативного пошуку первинної оперативно-розшукової інформації підрозділами кримінальної поліції.

Виклад основного матеріалу. Оперативний пошук первинної оперативно-розшукової інформації підрозділами Національної поліції України в загальному розумінні - це комплекс дій оперативного працівника, направленого на отримання певних відомостей, які передбачені чинним законодавством і несуть у собі будь-які ознаки злочинної діяльності чи підготовки до неї певними особами, змін у злочинному середовищі, що можуть передувати перерозподілу сфер впливу, а також інших відомостей, що відображають раніше не відомі для органів поліції обставини чи події, тобто, кажучи іншими словами, первинної оперативно-розшукової інформації.

Водночас щодо відомостей, які складають первинну оперативно-розшукову діяльність, сьогодні існує понад декілька десятків варіацій, наданих фахівцями у сфері оперативно-розшукової діяльності. Однак, на нашу думку, найбільш доцільним є визначення, надане авторським колективом монографії ПОРІ, що полягає в тому, що первинна оперативно-розшукова інформація - це сукупність раніше невідомих відомостей, які одержані в установленому нормативно-правовими актами України порядку, про злочинні наміри осіб та їхні зв'язки, предмети, факти, події і процеси криміногенного характеру та осіб, які переховуються від органів розслідування, суду, ухиляються від відбування кримінального покарання, а також безвісно відсутніх осіб та невпізнаних трупів, що становлять оперативний інтерес для ОВС. До джерел отримання первинної оперативно-розшукової інформації доцільно віднести:

1) заяви та повідомлення громадян України, іноземних громадян або осіб без громадянства;

2) повідомлення осіб, які конфіденційно співпрацюють з ОВС; $\mathrm{OBC}$;

4) публікації (матеріали) засобів масової інформації;

5) матеріали органів дізнання, досудового слідства та суду;

6) запити та інформацію спеціальних служб і правоохоронних органів іноземних держав, міжнародних установ та організацій;

7) орієнтування органів і підрозділів МВС України, в тому числі матеріали оперативно-технічних підрозділів та оперативної служби, що отримані ними в установленому законом порядку, в яких містяться дані щодо раніше невідомих подій, фактів або осіб, котрі не $\epsilon$ об'єктами справ, відносно яких проводяться оперативно-технічні заходи, візуальне спостереження чи оперативна установка;

8) офіційні листи та інші матеріали правоохоронних органів України;

9) матеріали контрольно-спостережних справ;

10) запити, офіційні листи та інші матеріали контрольних органів, органів державної влади та управлінь України, органів місцевого самоврядування, підприємств, установ та організацій;

11) матеріали із комп ютерної мережі Інтернет $[1$, с. 56$]$.

Водночас, аналізуючи положення чинного законодавства, зокрема Закону України «Про оперативно-розшукову діяльність», можна дійти висновку, що законодавчо способи отримання первинної оперативно-розшукової інформації, зокрема шляхом оперативного пошуку, передбачені в ст. ст. 7, 8 вказаного Закону як права та обов'язки підрозділів. Однак фактично практика роботи працівника кримінальної поліції свідчить, що сьогодні оперативний пошук у загальному вигляді відбувається шляхом:

- опитування громадян (гласно та негласно) - 32,6\%;

- залучення осіб до негласного та конфіденційного співробітництва $-18,2 \%$;

- проведення оперативно-розшукових заходів, що тимчасово обмежують права та свободи громадян - 16,3\%; 
- аналізу публікацій у $3 \mathrm{MI}-8,9 \%$; $7,1 \%$;

- взаємодії з іншими правоохоронними органами

- взаємодії з населенням, громадськими формуваннями - 6,5\%;

- моніторингу та аналізу інтернет-ресурсів, Телеграм-каналів, месенджерів, Інстаграм, Фейсбуку та інших соціальних мереж чи інтернет-платформ - 5,6\%;

- інше - 4,8\%.

Водночас слід відмітити, що такий розподіл було нами зроблено не із врахування кількості чи якості отриманої первинної оперативно-розшукової інформації, а саме за періодичністю здійснення таких заходів працівниками кримінальної поліції в повсякденній роботі.

Разомізциманалізсучасноїкримінальноїобстановки, способу життя населення, використання все частіше злочинним елементом електронних способів зв'язку дає змогу дійти висновку, що необґрунтовано мало використовуваним $\epsilon$ способи, пов'язані з аналізом та моніторингом як інтернет-ресурсів, так і соціальних мереж чи інших електронних платформ спілкування населення.

Зокрема, наприклад, не для кого не $\epsilon$ сьогодні новим, що саме за допомогою інтернет-ресурсів, електронних менеджерів і створених на їх основі каналів, чатів, співтовариств тощо відбувається розповсюдження наркотичних засобів, психотропних речовин та їх аналогів.

Так, Т.О. Чистанов зазначає, що класичний спосіб збуту наркотичних засобів сьогодні здійснюється шляхом залишення їх у схованках, так званих «закладках», що має на увазі організацію безконтактного збуту, коли координація діями й обмін інформацією співучасниками, а також із замовником здійснюється за допомогою телекомунікаційних мереж і мобільних додатків, таких як Telegram, Viber, WhatsApp, Jabber і т.д.

3 причини складної ситуації у сфері незаконного обігу наркотичних засобів необхідно вживати заходів щодо контролю за діяльністю інтернет-сервісів у сфері телекомунікацій (Viber, WhatsApp, Telegram, Jabber і т.д.). У всьому світі розробники мобільних додатків у сфері телекомунікацій слідують сучасним тенденціям захисту переданої інформації, збереження приватності й неможливості потрапляння інформації в публічний доступ. Правоохоронні органи не мають можливості відслідковувати координаційні вказівки організаторів незаконного обороту, у свою чергу це ускладнює отримання інформації, яка на стадії попереднього і судового слідства могла б стати ключовим доказом причетності осіб до злочинної діяльності. Наприклад, розробники месенджера WhatsApp використовують технологію наскрізного шифрування, яка не дозволяє нікому іншому, включно з організацією WhatsApp, прочитати надіслані повідомлення. Ще більш потужні алгоритми захисту інформації використовуються в месенджері Telegram. Крім шифрування, месенджер Telegram має функцію «секретного чату», повідомлення в якому видаляються автоматично в залежності від часу, встановленого користувачем, на серверах Telegram листування теж не зберігається. Таким чином, інформація, передана між співучасниками незаконного обігу наркотиків, надійно захищена i недоступна для правоохоронних органів.

Існує безліч сайтів і сторінок у соціальних мережах, що займаються продажем курильних сумішей «Спайс», синтетичних наркотиків, так званих «Сіль», «Шоколад», різних реагентів тощо [2].
Враховуючи вказане, зрозуміло, що оперативні працівники повинні отримувати первинну оперативно-розшукову інформацію саме шляхом моніторингу інформації таких груп, установлювати назви Телеграм-каналів, що виконують функції продажу наркотичних засобів та речовин. Водночас практика свідчить, що розроблений Харківським національним університетом внутрішніх справ Чат-Бот «СтопНаркотик» сьогодні здебільшого використовується здебільшого як спосіб припинення розповсюдження наркотиків, а не стає первинною оперативно-розшуковою інформацією для подальшого виявлення всіх осіб, що сприяють та розповсюджують наркотичні засоби.

До того ж щодо доцільності використання можливостей Інтернету, соціальних мереж та подібного прямо вказує фактична можливість отримання таким чином інформації первинного характеру стосовно злочинів проти статевої свободи і статевої недоторканності. Так, наведемо як приклад:

- у Фесбуці, Інстаграм та інших соціальних мережах досить часто викладають відео щодо встановлення громадянами осіб, які здійснюють дії сексуального характеру стосовно дітей [3], при цьому коментують час, місце таких дій та досить часто навіть затримують таких осіб та записують на відео анкетні дані таких осіб чи навіть їхні зізнання;

- шляхом аналізу Інтернет-контенту оперативні працівники здатні виявляти сайти, що розповсюджують відео та фото порнографічного характеру, в яких містяться відомості щодо вчинення злочинів указаного виду.

Водночас аналогічна ситуація склалась й з відомостями стосовно осіб, що вчиняють злочини проти власності (у великій кількості викладають відео та фото осіб, що вчиняють кишенькові крадіжки, квартирні крадіжки, грабежі та навіть розбої), хуліганські дії з обтяжуючими ознаками, нанесення тілесних ушкоджень, дорожньо-транспортні пригоди тощо.

До того ж сьогодні в Інтернет-мережі, соціальних мережах та електронних меседжерах досить розповсюдженим $є$ викладення відомостей щодо викрадених транспортних засобів, місць, де їх бачили інші особи. До речі, якщо вже говорити про злочини, пов'язані з викраденням автотранспорту, то досить ефективним $\epsilon$ аналіз торгівельних інтернет-площадок, зокрема частим $€$ після викрадення автомобіля виклад інформації на сайтах із продажу авто інформації про розбір конкретної марки та моделі авто, можна побачити деякі запчастини автомобілів, що $є$ характерними для викраденого (наприклад, автодиски) тощо. (Наприклад, прокуратурою Італії при суді міста Ріміні проводиться розслідування у кримінальній справі, відкритій стосовно невстановлених осіб, які у складі злочинної організації здійснили викрадення транспортних засобів на території Італії. Під час проведення розслідування італійські правоохоронці встановили, що деякі транспортні засоби реалізуються за допомогою Інтернету на території України. У рамках міжнародної правової допомоги працівники кіберполіції встановили осіб, які збували в Україну викрадені транспортні засоби та місця їхнього зберігання. 21 серпня в трьох регіонах України були проведені санкціоновані обшуки, за результатами яких вилучено майже три десятки викрадених мотоциклів. Співробітники кіберполіції встановили осіб, які на території України 
збували викрадений транспорт для мотокросу. Реалізація мотоциклів відбувалася за допомогою спеціального веб-ресурсу. Крім того, встановлено й місця зберігання викраденого майна) [4].

Також аналіз інтернет-ресурсів може надати можливість установити місцезнаходження особи, їі контакти, зацікавлення та інші відомості, що можуть бути оперативно важливими (наприклад, відомості не тільки із соцсторінок особи, а із сайтів «Всі мешканці», «Автономера» (відомості про авто) ua.carplates.app, [5]. (Hanpuклад, один з інтернет-ресурсів визначає, що сучасний Інтернет надає для цього масу можливостей: пошук людей у соціальних мережах, спеціалізованих каталогах Міжнародних організацій, що займаються розшуком зниклих друзів і родичів, через спеціальні пошукові системи людей в Інтернеті, а також через месенджери або служби обміну повідомленнями, IP-телефонію і т.д. Дані способи допоможуть у пошуку людини в будь-якій країні світу. Найбільш простою і поширеною можливістю пошуку людини в Інтернеті є використання пошукових систем. Деякі пошукові системи, наприклад Яндекс, мають у своєму арсеналі систему пошуку людей. Дана система здійснює пошук за доступними даними соціальних мереж й інших сайтах. Недолік використання пошукових систем полягає в тому, що вони видають масу інформації, яку складно обробити і переглянути. 3 іншого боку, пошукові системи роблять пошук, охоплюючи найбільше число сайтів. Також у пошукових системах можна зробити пошук людини по фотографії.

Крім звичайного пошуку людини по імені та прізвищу в Google, можна скористатися веб-сайтами, які представляють собою безкоштовні пошукові системи людей. Дані сайти здійснюють пошук людей із соціальних мереж, телефонних книг, по веб-сайтам, за електронними адресами, фото і т.д. Перейшовши на такий сайт, потрібно вказати ім'я та прізвище. На деяких сайтах можливий пошук по імені користувача, нику, школі, за адресою, електронною адресою, номером телефону й інших парамempax: peekyou.com, pipl.com, webmii.com, ussearch. com - СШA, spokeo.com, nfobel.com, zabasearch.com, paginebianche.it - Італія, уаsni.de - Німеччина). До того ж соціальні мережі в даний час містять вже величезну кількість створених профілів, наприклад, Фейсбук повідомив, що в цій соціальній мережі знаходяться більше 2000000000 (2 мільярдів) людей. Таким чином, соціальні мережі надають відмінну можливість зробити пошук людини по прізвищу та імені. Передусім варто відзначити, що існують сайти, які здійснюють пошук імен та прізвищ відразу по всіх або деяких соціальних мережах, що істотно полегшує завдання пошуку. social-searcher.com - пошук профілів у мережах за прізвищем, ім'ям у реальному часі: yandex.ru/people - пошук людей в мережах від Яндекс, uvrx.com - пошук Google по окремих соціальних мережах, poisksocial.ru - пошук у соціальних мережах. Звичайно, дані пошуковики по сочіальних мере жах не охоплюють абсолютно всі соціальні мережі, тому в якихось випадках може знадобитися зробити пошук, безпосередньо перейшовши на сайти соціальних мереж. Facebook, Google Plus, Xing, Twitter, В Контакте, Однокласники, Мій свіm mail.ru, У колі друзів, Instragram, Linked in.

Крім цього, велика частина людей на землі використовує служби обміну повідомленнями (Месенджери) або програми для телефонних дзвінків через Інтернет, які також надають можливості пошуку своїх користувачів. Звичайно, кожен користувач месенджера може заборонити видавати його профіль у пошуку користувачів, але роблять це зовсім не всі. Запустивши програму на своєму мобільному пристрої або комп'ютері, також можна зробити пошук людей по імені та прізвищу. Найвідоміші програми наведені в Skype, ICQ, WhatsApp, Viber, Telegram, Snapchat) [6].

Також неможливо оминути увагою те, що в мережі Інтернет швидше, аніж працівники поліції встигають такі факти реєструвати, з'являється інформація про новітні способи шахрайств.

Висновок. Отже, підсумовуючи наведене, слід резюмувати, що сьогодні використання оперативного пошуку в мережі Інтернет, соціальних мережах та електронних месенджерах може надати можливість оперативним працівникам отримувати додатково до 20\% первинної оперативно-розшукової інформації, що становить оперативний інтерес.

\section{Література}

1. Баб'як А.В. Отримання та використання первинної оперативно-розшукової інформації оперативними підрозділами ОВС України : монографія. Львів : Каменяр, 2010.167 с.

2. Чистанов Т.О. Незаконный сбыт наркотических средств с использованием телекоммуникационных сетей и устройств. URL: https://research-journal.org/law/ nezakonnyj-sbyt-narkoticheskix-sredstv-s-ispolzovaniemtelekommunikacionnyx-setej-i-ustrojstv/.

3. Активисты поймали педофила. URL: https: / / www.facebook.com/watch/?v=1757294501243980.

4. В Украине нашли три десятка угнанных в Италии мотоциклов. URL: https://ua.korrespondent.net/ukraine/ 4003209-v-ukraini-znaishly-try-desiatky-vykradenykh-v-italiimototsykliv.

5. Проверить автомобиль по Гос. Номеру. URL: https://ua.carplates.app/.

6. Как найти человека в Интернете бесплатно: 10 способов бесплатного поиска людей через Интернет. URL: https: //ru-geld.de/people-search/in-internet.html.

Волошина М. О., кандидат юридичних наук, докторант Харківського національного університету внутрішніх справ

Шендрик В. В., доктор юридичних наук, професор, заслужений юрист України,

завідувач кафедри оперативно-розшукової діяльності та розкриття злочинів Харківського національного університету внутрішніх справ 